\title{
Impacts of Import Tariff Removal and Changes in International Prices on the Applicability of the Traditional HOS Trade Theory*
}

\author{
Mauricio Vaz Lobo Bittencourt**
}

\begin{abstract}
This paper examines the effects of agricultural and nonagricultural trade policy changes in the Brazilian economy using a computable general equilibrium model (CGE). An extended Salter-Swan model is employed to verify if the Stolper-Samuelson theorem (SST) holds after having a trade barrier removed and the consequences in terms of prices, production and resources allocation. Results show that the Stolper-Samuelson hypothesis is reversed when imports and domestic goods are poor substitutes. Reduction in import tariff increases national income, which implies that inappropriate trade policy adjustments can stand in the way of promoting rapid and equitable economic growth. Further, our results show that changes in relative factor prices in Brazil depend not only on changes in commodity prices, as in the SST, but also on changes in the balance of trade and factor endowments. This study mainly proposed to verify a specific result from a theoretical trade model, which makes important to stress the carefulness about the empirical results obtained to the Brazilian trade policies.
\end{abstract}

Keywords: Stolper-Samuelson theorem. CGE model. Trade distortion.

JEL Classification: C68; F14; O54.

\section{Introduction}

This study investigates some of the important consequences of trade liberalization on the Brazilian economy in general, and on Brazilian agriculture in particular, aiming to verify if the Stolper-Samuelson theorem holds. Since reductions in import tariffs or changes in foreign prices of tradable goods have strong effects on domestic resource allocation among production sectors, this paper uses a singlecountry computable general equilibrium model (CGE) to assess the gains from unilateral reduction in tariffs and a decrease in import prices of traded goods in Brazil.

The use of a single-country CGE model is justified by Melo and Tarr (1992) who used a similar type of model to estimate effects of the removal of protection in

\footnotetext{
* The author would like to acknowledge the financial support given by Capes Foundation (Fundação Capes, Brazil) and also David Kraybill, Glenn Harrison, Ratapol Teratanavat, and Serdar Sayan for their valuable suggestions and comments.

* * Professor do Programa de Pós-Graduação em Desenvolvimento Econômico da Universidade Federal do Paraná (PPGDE/UFPR). Bolsista de Pós-Doutorado do CNPq na Ohio State University (OSU).E-mail: mbittencourt@ufpr.br
} 
the U.S. They argued that multi-country models might overestimate the terms of trade effects induced by a unilateral reduction in protection.

According to Bautista et al. (2001), many studies take into account the effect of indirect government interventions in the agricultural sector. These studies go beyond the sectoral orientation of traditional agricultural policy analysis, which is good, but they have relied mostly on partial equilibrium approaches. As noted by Hertel (1999), traditional agricultural economic analysis has tended to focus only on commodities and associated factor returns, without considering sectoral interrelations and feedback loops between production sectors and macroeconomic policies. These arguments strengthen the case for use of a CGE model to evaluate changes in the agricultural sector due to changes in trade policies in the economy.

The main objective of this study is to verify if the Stolper-Samuelson Theorem (SST) holds in a CGE model after reduction in distorting trade policy instruments such as import tariffs in the Brazilian economy.

The paper is organized as follows. The next section reviews the literature on trade-oriented CGE models. Section 3 presents the Thierfelder and Robinson ${ }^{1}$ extension of the Swan-Salter model and discusses its conclusions regarding SST. Section 4 presents a Brazilian CGE and discusses data sources. Section 5 discusses the design of the simulation and the main results. The conclusions are in Section 6.

\section{Literature Review}

Since we will try to verify what happens with factor prices, income, and other economic variables in the Brazilian economy through the Stolper-Samuelson theorem when there are import price changes, under different levels of import tariffs, the question becomes: Does the Stolper-Samuelson theorem hold with a distortion reduction in the trade sector in a model with imperfect trade substitution?

Bautista and Thomas (1997) examined the impact of alternative trade policy adjustments on income and equity effects, focusing on low-income rural households in the Philippines. Using a CGE model and a SAM for 1979, they simulated three different trade policies: import rationing, uniform surcharges on imports, and trade liberalization. Markets for goods, factors and foreign exchange were assumed to respond to changing demand and supply conditions. The model has five agricultural sectors, three rural and two urban households, and four primary factors. The simulation results showed that with a uniform reduction in import tariffs, there was a $50 \%$ reduction in the current-account deficit, suggesting that this is an attractive policy reform. The results indicate that the worse possible situation for the economy as a whole would be to impose an import tariff. Trade liberalization seemed to be the best among the three policies in terms of both efficiency and equity con-

Thierfelder and Robinson (2002). 
cerns. The authors conclude that rural Philippine households were penalized by the imposition of import rationing and general import surtax. Fast and equitable growth cannot happen with inappropriate trade policies.

Bautista et al. (2001) compared partial and general equilibrium approaches in evaluating the effects of policy intervention in agriculture in Tanzania. They considered two assumptions regarding substitutability between domestically produced and imported goods: perfect versus imperfect substitutability of imports and domestically produced goods. The study had four simulations. The first was an import substitution industrialization strategy with an import tariff on non-agricultural goods. The second simulation was the same as the first with a fixed exchange rate. The third and fourth simulations imposed a tax on agricultural exports with free and fixed exchange rates. The general equilibrium results suggested that trade policies have a less negative effect on relative prices in agriculture than those indicated by partial equilibrium analysis. The non-agricultural tariff reduced the terms of trade for this sector. The imposition of an export tax on all agricultural sectors with a fixed exchange rate was responsible for a lower deterioration of the terms of trade in comparison with that of a free exchange rate.

Cattaneo, Hinojosa-Ojeda and Robinson (1999) developed a CGE model for Costa Rica using a SAM for 1991, consisting of 25 production sectors, seven types of households and one aggregate enterprise account. They simulated trade liberalization under fixed and free exchange rates, with possible compensation for the loss of tax revenue through an increase in taxation in the domestic market. The results obtained suggest that the changes in domestic prices are significant due to trade liberalization. However, the effects on income were very small, because all households receive some type of capital income. With tariff reduction, there was an increase in GDP due to the increase in agricultural production. ${ }^{2}$

Davies, Rattso and Torvik (1998) studied the short-run consequences of trade liberalization in Zimbabwe using a five-sector CGE model based on a SAM for 1985. Full liberalization would lead to an increase in intermediate imports that could increase the domestic production of final goods. Demand for imported final goods would increase more than demand for domestic final goods. To alleviate this problem, exchange rate devaluation could be undertaken. They conclude that trade liberalization creates short-run problems ${ }^{3}$ and this is the main reason liberalization has been so controversial.

$2 \quad$ Chou, Chu and Wang (1997) also applied a single-country CGE to Taiwan and concluded, with no surprise, that the economic gains from trade liberalization are positive and with particular benefits for households in terms of income and consumption.

3 These problems include consumption booms, short-run contractions, drops of savings, demand switching to foreign goods, and growing trade deficits. 


\subsection{CGE Studies about Trade in Brazil}

There are many studies that capture the impacts of trade policies and regional integration on the Brazilian economy. Some of them are partial equilibrium studies (CARVALHO; PARENTE, 1999); some other studies use a general equilibrium approach to study Mercosur policies, such as Campos-Filho (1998) and Flores (1997); and others, such as Haddad (1999), Haddad and Azzoni (2001), and Carneiro and Arbache (2002), analyze issues related to unilateral liberalization and their implications for resource allocation.

Carneiro and Arbache (2002) use a CGE model to analyze the labor market reactions to trade liberalization. They find that trade liberalization improves economic welfare by means of greater output, lower domestic prices, and higher labor demand, but the benefits of this economic improvement tend be appropriated by the most skilled workers in the most trade-oriented sectors.

Haddad, Domingues and Perobelli (2002) evaluate three different trade liberalization scenarios through an interregional model integrated to a CGE model and a national CGE model. Results show that the trade strategies tested are likely to increase the regional inequality in Brazil. Although this study evaluates regional short run effects of trade liberalization, it does not address poverty, which is very heavily affected by the regional distribution of resources, population, and production sectors in the Brazilian economy.

Monteagudo and Watanuki (2002) investigated the impact on Mercosur after two different free trade agreements: Free Trade Area of Americas (FTAA) and free trade with European Union (EU). Their findings suggest that with the removal of tariffs and non-tariff barriers, the FTAA seems to be a better option for Mercosur countries. The integration seems to have a strong effect in Brazil, stimulating the export specialization in manufacturing industries.

Flores (1997) uses a CGE model with imperfect competition to evaluate the gains from Mercosur for Argentina, Brazil, Paraguay, and Uruguay. The results, in general, show that the gains are greater for Uruguay than for the other countries. Outcomes for Brazil and Argentina seem to be closely linked.

Barros et al. (2000) is one of a few studies that address the impact of trade liberalization on poverty in Brazil. They used a CGE model and simulated an increase of protection to the same level as in 1985. They conclude that trade liberalization is beneficial for the whole country, but especially for both urban and rural poor households.

Harrrison et al. (2002, 2003), Bittencourt (2004), Ferreira Filho and Horridge (2004, 2006), and Bittencourt, Larson and Kraybill $(2008,2010)$ use CGE models to investigate the main impacts of trade liberalization on poverty and income distribution. Their general results are similar. These studies seem to stress that a trade liberalization policy improves the income distribution. However, Bittencourt (2004) 
and Bittencourt, Larson and Kraybill $(2008,2010)$ conclude that elimination of import tariffs reduces welfare for lower income families. According to Ferreira Filho and Horridge (2006), trade policies bring positive effects in the poverty reduction, mainly in the agricultural sector. Some families, but not necessarily the poorer ones, can experience decrease in income after trade liberalization.

Harrrison et al. (2002, 2003), and Ferreira Filho and Horridge (2004) show that reduction of poverty and in the income inequality in Brazil are possible after a multilateral analysis of various trade policies, such as Mercosur, FTAA, and European Union agreements.

\subsection{The Stolper-Samuelson Theorem in CGE Models}

The Stolper-Samuelson Theorem (SST) based on the Heckscher-Ohlin-Samuelson (HOS) model captures the link between an industry's price and the return to its intensively used factor of production. The link between prices of goods and prices of factors through the production structure, holding technology constant, is the heart of SST. According to Rassekh and Thompson (1997), the specific-factors model assumes every industry is characterized by productive capital used only in that industry, creating a direct link between price of the output and its specific factor. Cheng, Sachs and Yang (2002) states that, since with the opening-up of international trade the price of a country's comparative advantage good rises, SST implies that international trade benefits a country's abundant factor and hurts its scarce factor.

Lloyd (2000) argues that there is doubt about the generality of SST. He emphasizes that the theorem is the foundation of political economy models for evaluating tariffs and other taxes and government interventions.

According to Rassekh and Thompson (1997) there are not many empirical studies that employ SST because the real world does not appear to conform to its theoretical assumptions. They give an example of different types of labor inputs that can be found in many production processes instead of the small number considered in empirical studies. Leamer (1984) points out that direct econometric estimation of SST is difficult because of the high degree of collinearity between prices of goods and prices of factors.

Gopinath and Roe (1999) studied the application of SST and the Rybczynski theorem to U.S. agriculture, trying to explain inter-sectoral growth due to changes in factors of production such as labor. The procedure used was different than the one used in this paper. They applied a joint general equilibrium and econometric model to provide insights into the structure of agriculture supply, factor returns and linkages to the rest of the economy. The Rybczynski like effects in agriculture seemed to be positive, suggesting that an increase in sector specific endowments causes an expansion in all agricultural sub-sectors. The response of factor returns 
to increases in output prices (Stolper-Samuelson like effects) followed the pattern of relative factor intensity.

Robinson and Thierfelder (1999) evaluate the impact of changes in the tax structure on real wages using a CGE model. They evaluate an import tariff and import rationing reduction, which would increase the real wage and depreciate the real exchange rate. They identify some transfer effects that dampen the magnification effect of a price change on factor returns but do not reverse the Stolper-Samuelson results.

\section{An Extension of the Swan-Salter Model}

One way to accomplish the main goal of this paper is through the appraisal of the theoretical results obtained by Robinson and Thierfelder in the standard CGE model developed at IFPRI ${ }^{4}$ (LOFGREN; HARRIS; ROBINSON, 2001). They extend the Swan-Salter model with both traded and non-traded goods, where imports and domestic goods are imperfect substitutes in consumption, as in Armington (1969), specifying semi-traded instead of non-traded goods. They include both domestic and traded goods so the model has a real (Swan-Salter) exchange rate. If imports and domestic goods were perfect substitutes, the model would converge to the standard Heckscher-Ohlin-Samuelson (HOS) model and, of course, the Stolper-Samuelson theorem would be valid.

Thierfelder and Robinson (2002) begin with the Swan-Salter model and extend it by incorporating factor markets and semi-traded goods. Changes in relative factor prices depend on changes in world prices of goods, factor endowments and the trade balance. They concluded that the inclusion of semi-traded goods weakens the magnification effect of both the Stolper-Samuelson and Rybczynski theorems, and that the sign of the Stolper-Samuelson effect is reversed when imports and domestic goods are poor substitutes.

The Thierfelder and Robinson model is a HOS general equilibrium type of model with one country, two production sectors, two inputs and three goods (1-22-3 model). The country produces two goods $\mathrm{E}$ and $\mathrm{D}$, where $\mathrm{E}$ is exported and is not consumed, and $\mathrm{D}$ is consumed in the domestic market, and $\mathrm{M}$ is the imports of a good that is consumed but not produced domestically. Absorption is given by:

$$
Q=F\left(D, M ; \sigma_{Q}\right)
$$

where $\sigma_{Q}$ is the elasticity of substitution in demand and $F\left(D, M ; \sigma_{Q}\right)$ is a production function, defined as CES or Cobb -Douglas function. Assuming no technical change, and that absorption is homothetic, convex and twice differentiable, in competi-

International Food Policy Research Institute. 
tive equilibrium unit costs (factor wages, $\mathrm{W}$ ) will equal market prices. To close the model, the balance trade equation is given by:

$$
P^{M} \cdot M=\Phi \cdot P^{E} \cdot E
$$

where $\Phi$ gives the ratio of import expenditures and export earnings, $\mathrm{PM}$ is the import price and $\mathrm{PE}$ is the export price. Equation (2) implies that the HOS model is a special case of this expression when $\Phi=1$, and trade is balanced. Therefore, the higher $\Phi$, the worse is the trade balance.

Under the small country assumption in international trade, $\mathrm{P}^{\mathrm{M}}$ and $\mathrm{P}^{\mathrm{E}}$ are fixed. Assuming that $\mathrm{E}$ is capital-intensive and $\mathrm{D}$ is labor-intensive, capital's value share in $E$ is greater than its value share in $\mathrm{D}\left(\theta_{\mathrm{KE}}>\theta_{\mathrm{KD}}\right)$, and the share of the total capital stock used in $\mathrm{E}$ is greater than the share of the labor force used in $\mathrm{E}\left(\lambda_{\mathrm{KE}}>\right.$ $\lambda_{\mathrm{LE}}$ ). The elasticities of transformation between $\mathrm{E}$ and $\mathrm{D}$ and substitution between capital and labor are given respectively by $\Omega$ and $\sigma$.

The model produces a link between changes in relative prices and relative wages given by:

$$
\left(\hat{W}_{K}-\hat{W}_{L}\right)=\frac{1}{|\theta|}\left(\hat{P}^{E}-\hat{P}^{D}\right)
$$

where (^) represents relative change, $|\theta|=\theta_{\mathrm{KE}}-\theta_{\mathrm{KD}}, \mathrm{W}_{\mathrm{K}}$ and $\mathrm{W}_{\mathrm{L}}$ are returns in the capital and labor markets. Expression (3) demonstrates the SST in the HOS model with both tradable goods and exogenous prices, where relative wages would be dependent only on relative prices. Since $|\theta|<1$, the change in relative wages is greater than the change in relative prices, a result known as the magnification effect. ${ }^{5}$ Expression (3) can be used to show that when one price changes, one wage increases and other decreases, as predicted by the SST.

The changes in relative prices on the right-hand-side of expression (3) can be expressed as:

$$
\left(\hat{P}^{E}-\hat{P}^{D}\right)=\frac{1}{\left(\sigma_{Q}+\Omega\right)}\left[\left(\hat{P}^{E}-\hat{P}^{M}\right)\left(\sigma_{Q}-1\right)-\hat{\Phi}+\frac{1}{|\lambda|}(\hat{L}-\hat{K})\right]
$$

where $\mathrm{L}$ and $\mathrm{K}$ are the amounts of labor and capital; $|\lambda|=\lambda_{\mathrm{KE}}-\lambda_{\mathrm{LE}}$; and $\lambda_{\mathrm{ij}}$ is the share of total supply of factor $i$ used in sector j. Equation (4) shows how the econ-

Demonstrated by Jones (1965). 
omy moves along the production possibility frontier as a function of changes in the balance of trade, world prices and factor endowments.

An important result can be obtained by combining equations (3) and (4), where changes in relative wages is a function of changes in world prices, the balance of trade and factor endowments. As the elasticity of substitution $\left(\sigma_{Q}\right)$ goes to infinity, the results of the HOS model are exactly reproduced, since in the limit imports and domestic goods are perfectly substitutes $\left(\hat{P}^{D}=\hat{P}^{M}\right)$. The main result is that the SST holds because changes in relative wages depend only on changes in world prices.

Therefore, the main result of the extended Swan-Salter model based on Thierfelder and Robinson (2002) is that with no change in endowments and balance of trade, we have the following result:

$$
\left(\hat{W}_{K}-\hat{W}_{L}\right)=\frac{1}{|\theta|}\left[\frac{\left(\sigma_{Q}-1\right)}{\left(\sigma_{Q}+\Omega\right)}\right]\left(\hat{P}^{E}-\hat{P}^{M}\right)
$$

If we compare (5) with (3), we can note that the magnification effect of the SST is reduced by the second ratio on the right-hand-side, since $\Omega>0$, implying that this term is less than one. Therefore, the higher is the export trade elasticity $(\Omega)$ and the closer is the elasticity of substitution in demand $\left(\sigma_{\mathrm{Q}}\right)$ to one, the weaker is the link between changes in prices and changes in relative wages.

If $\sigma_{\mathrm{Q}}<1, \mathrm{M}$ and $\mathrm{D}$ are weak substitutes. An increase in $\mathrm{P}^{\mathrm{M}}$ would lead to an increase in the ratio $\mathrm{P}^{\mathrm{E}} / \mathrm{P}^{\mathrm{D}}$ = real exchange rate, implying a depreciation in the real exchange rate, reduction in the production of $\mathrm{D}$ and an increase in $\mathrm{E}$. The exchange rate depreciates to increase exports through a reallocation of factors of production in order to increase the earnings from international sales to face the higher costs of the imports. The change in a commodity price $\left(\mathrm{P}^{\mathrm{M}}\right)$ has an effect on wages opposite to that predicted by the HOS model.

This section has shown that under imperfect substitutability of $D$ and $M$ in a CGE model the magnification effect in the SST is reduced, and the sign of the SST result can be the opposite of what would be predicted by the HOS model.

\section{Model and Data Description}

The model used in this study is based on Lofgren, Harris and Robinson (2001), and has 48 equations divided into four blocks: prices, production and commodities, institutions, and system constraints. ${ }^{6}$

The detailed description of the main equations, sets, parameters and variables of the model can be found in Appendix A. 
It is a static CGE model with structural constraints on factor and good markets, and macroeconomic aggregates. There are two productive sectors: agricultural and non-agricultural, where the former is relatively labor-intensive and the latter relatively capital-intensive. Each sector produces one commodity (agricultural or non-agricultural commodities), combining three factors of production: labor, capital and land. Capital and labor are assumed to be sector-specific, immobile, fully employed and having a flexible wage. There is no money, interest rate or credit market in the model, apart from the savings-investment identity and the numeraire.

The model assumes that producers maximize profits subject to given technology and households maximize utility subject to budget constraints. Technology and utility functions are based on Cobb-Douglas functions with fixed supplies of factors. Therefore, producers and households demand factors and commodities at market-clearing prices, and all market prices and quantities are determined endogenously, except for the world import (non-agricultural) and world export (agricultural) commodity prices, which are exogenous due to the small country assumption in the world market. There are two types of households: urban and rural. Household income is a fixed share of factor incomes paid by production sectors.

Production technology is represented by a set of nested Cobb-Douglas and Leontief functions. Domestic output in each sector is a Cobb-Douglas function of value added and aggregate intermediate inputs. Value added is a Cobb-Douglas function of primary inputs, while intermediate input use is defined by fixed input-output coefficients.

It is assumed that household income is allocated in fixed shares to savings and consumption. Investment is savings-driven, implying that the value of total investment spending is determined by the value of savings. Investment spending is allocated to commodities in such a way that there is a fixed ratio between the quantities.

Sales taxes are fixed shares of producer commodity prices, and the government consumes fixed commodity quantities (in real terms), paying prices available in the market. Government transfers to households are fixed in nominal terms since they are CPI-indexed. Government savings is simply a residual of expenditures and revenues to balance the government account.

With respect to the rest of the world, imports and domestic production sold for the domestic market are considered imperfect substitutes and the value of the elasticity ${ }^{7}$ of substitution between imported and domestic nonagricultural commodities $\left(\sigma_{\mathrm{Q}}\right)$ is 1.41, on average, according to Tourinho, Kume and Pedroso (2002). The composite good is a CES function of the domestic and imported nonagricultural commodities. In the same way, for producers, there is imperfect transformability between exports and domestic production to be sold in the domestic market. The

Other elasticity estimates are borrowed from Asano and Fiuza (2001).

BITTENCOURT, M. V. L. Impacts of Import Tariff Removal and Changes in International... 
assumed value of elasticity of transformation between exports and domestic sales of agricultural commodity is 2 . The total output is a CET function of the amounts sold in the foreign and domestic markets. Foreign savings, equal to the current account deficit, is fixed.

The model is homogeneous of degree zero in prices, and the consumer price index (CPI) is used as numeraire. Three main closures are used in the model: 1) government: flexible government savings and fixed direct tax rates; 2) savings-investment: savings-driven investment with fixed marginal propensity to save for all households and flexible capital formation; and 3) ROW: fixed foreign savings and flexible exchange rate.

The model uses an aggregated version of a Brazilian Social Accounting Matrix (SAM) that was constructed for 1995-96 by Andrea Cattaneo of the Economic Research Service's Resource and Environment Policy Branch (USDA) (CATTANEO, 1999), and it was primarily generated from 1995 input-output tables for Brazil (IBGE, 1997a), national accounts (IBGE, 1997b), as well as Agricultural Census data for 1995-96 (IBGE, 1998).

Since the paper's proposal is a theoretical model evaluation applied to Brazil, it is justifiable the use of a 1995-96 SAM, instead of using a newer database, such as a 2005 SAM. Comparing the Input-Output tables for 1995 and 2005, we have: (i) the imports coefficient (total imports/PIB ratio) increase from 9,5\% in 1995 to $11,5 \%$ in 2005; (ii) the effective imports tax burden (imports taxes/total imports) decrease from $8 \%$ in 1995 to $3,6 \%$ in 2005 . Therefore, in order to understand the structural changes in the Brazilian trade tax policies and to answer questions of the specified theoretical model, it is reasonable to make use of the 1995-96 SAM in this paper.

According to Cattaneo (1999), total labor, land and capital value added were allocated across the agricultural activities based upon the Agricultural Census. The SAM captures small and large-scale productive technologies. Four agricultural categories (annuals, perennials, livestock, and other agriculture) are disaggregated by holder size (small and large). The original SAM also includes three manufacturing activities, three service activities, and 24 commodities. There are 18 labor categories; including 10 urban (further disaggregated by skill level and sector) and 8 agricultural (by skill level and region); 9 capital categories, 8 of which are agricultural and distinguished by holder size and region; and 12 land categories disaggregated by land type (arable, grassland, and forested) and region. Finally, the SAM includes five household accounts (rural and urban by income level), three tax accounts, a savings as well as inventory account, and one account each for enterprises, government, and rest-of-world (ROW). The aggregated version of the Brazilian SAM is in the Appendix B, representing the initial conditions that are perturbed by exogenous shocks. 


\section{Simulations and Results}

Model implementation follows two stages. In the first, the model is solved for the base without imposing any changes in parameters or exogenous variables (calibration). The base values are saved for comparison with the results of the simulations that are implemented in the second stage. In the calibration process, all parameters and variables values are obtained from the SAM, although elasticity values and factor stocks data are exogenous. The benchmark solution is expected to represent the state of the economy in real terms. A computer-based replication check is, then, applied using an accuracy test of computer code, which fails if a programming error arises when the model, via an iterative process, seeks the set of equilibrium prices. If such were the case, the functional form(s) of the model would prove inconsistent with data set, possibly due to unfeasible elasticity values. The replication check does not fail if a benchmark equilibrium is reached, which is basically the case when, after the model reproduces its corresponding value in the SAM.

In the second stage a set of exogenous variables or parameters is modified to illustrate a change in the trade policy or an exogenous shock on tradable goods prices. The model is then solved to find the solution compatible with the modifications in the base model (benchmark).

There are two sets of simulations divided into two different scenarios. In the first scenario there is a reduction in the import tariff. In the second scenario, since SST results are driven by changes in relative prices, there is a reduction in the prices of imported goods to emphasize the results obtained in the previous scenario.

The Armington elasticities used in the simulations and in the calibration were borrowed from Tourinho, Kume and Pedroso (2002), which estimated the Armington elasticities for 28 industrial sectors in Brazil for the period 1986-2001. The calibration procedure and the simulations will be performed through the use of the General Algebraic Modelling System (GAMS).

Scenario 1: smaller import tariff (less distorted economy).

The rationale of this set of simulations is to verify if the SST holds in a situation of less distortion in the market, with a reduction of $50 \%$ in the import tariff.

In this first scenario, we have the following simulations:

(i) Import tariff decreases by $50 \%$ with $\sigma_{\mathrm{Q}}<1$;

(ii) Import tariff decreases by $50 \%$ with $\sigma_{\mathrm{Q}}>1$.

The simulation results for the first scenario are shown in Table 1. In the first simulation, with $\sigma_{\mathrm{Q}}<1$, some variables seem to improve with less distortion in the market, which is an expected result. The reduction in import tariff has an effect equivalent to a reduction in the price of imported goods. There is a shift of 
resources from exports toward imports and domestic goods, and the exchange rate depreciates due to the deficit in the balance of trade. There is no reduction in the capital rent-wage gap as expected, which results in a violation of the SST.

The main indicators of the Brazilian economy show gains from the unilateral removal of the distortion, such as increase in total trade, higher household income, higher level of composite output, higher prices of factors of production, and higher net indirect taxes. The agricultural sector experiences most of the gains from trade, since the total agricultural trade increases (imports plus exports), which increases agricultural composite supply, that affects positively the rural households income and welfare.

The results from Table 1 seem to confirm the main findings of Harrrison et al (2002, 2003), Bittencourt (2004), Ferreira Filho and Horridge (2004, 2006), and Bittencourt, Larson and Kraybill (2008, 2010).

Table 1 - CGE Model Simulation Results for Scenario 1 (\% changes from base values)

\begin{tabular}{lcc}
\hline \multicolumn{1}{c}{ Variable } & Simulation 1 (a) & Simulation 2 (b) \\
\hline Absorption & 0.04 & 0.04 \\
GDP & 0.04 & 0.04 \\
Private Consumption & 0.06 & 0.06 \\
Agricultural Exports & 2.8 & 3.3 \\
Nonagricultural Exports & 2.0 & 2.4 \\
Agricultural Imports & 0.6 & -0.34 \\
Nonagricultural Imports & 1.9 & 2.3 \\
Net Indirect Taxes & 0.27 & 0.27 \\
Exchange Rate & 2.8 & 3.4 \\
Rural Households Income & 0.26 & 0.25 \\
Urban Households Income & 0.25 & 0.24 \\
Composite Agric. Commodity Supply & 0.58 & 0.60 \\
Composite Nonagric. Commodity Supply & 0.24 & 0.23 \\
Economy Wide Price of Capital & 0.41 & 0.39 \\
Economy Wide Price of Labor & 0.41 & 0.40 \\
Economy Wide Price of Land & 0.77 & 0.85 \\
Equivalent Variation for Urban households & 0.06 & 0.06 \\
Equivalent Variation for Rural households & 0.07 & 0.07 \\
Price of Exports (domestic currency) & 2.8 & 3.4 \\
Price of Imports (domestic currency) & -1.6 & -0.5 \\
\hline Source: Elaborated by the author. & & \\
\hline
\end{tabular}

Source: Elaborated by the author.

Note: (a) Simulation $1=50 \%$ decrease in import tariff with $\sigma_{\mathrm{Q}}=0.8$; (b) Simulation $2=50 \%$ decrease in import tariff with $\sigma_{\mathrm{Q}}=1.41$.

The second simulation, with $\sigma_{\mathrm{Q}}>1$, shows that the volume of trade increases, worsening the trade balance, due to reduction in the tariff on imports. The expected result would be once again the reduction in the gap between capital rent and wage. The exchange rate depreciates once again to increase exports to accommo- 
date the large import volume. This reduction in the distortion is responsible for the efficiency gains in the level of exports, household income, and composite output for both commodities. As Table 1 shows, the SST holds with high Armington substitution $\left(\sigma_{Q}>1\right)$, due to the reduction in the gap between capital rent and wage. The effects on the agricultural sector are very similar to those from previous simulation, with the exception of the decline in the agricultural imports mainly due to larger exchange rate appreciation in the second simulation.

Scenario 2: changes in international prices.

The rationale of this second set of simulations is to test if the SST holds after changes in the international prices of imports under a high level of trade distortion. Therefore, considering $\sigma_{Q}<1$, an exogenous change in the price of imports should lead to an opposite change in the factor price ratio, as we can verify in equation (5) in section 3. The opposite should happen when $\sigma_{Q}>1$.

In the second scenario, we have the following simulations:

(i) World prices of imported goods decrease by $20 \%$ with $\sigma_{Q}<1$;

(ii) World prices of imported goods decrease by $20 \%$ with $\sigma_{Q}>1$.

The results from simulation of the second scenario are showed in Table 2. The reduction in import prices with $\sigma_{Q}<1$ implies that since the price of essential import goods is reduced, there is an appreciation in the exchange rate in order to take advantage of the reduced price of imports. This happens through resource reallocation from the export sector to the domestic sector because of an increase in the relative price of domestic goods with respect to the price of exports. Exports become more expensive in the foreign market and import goods become cheaper, which shows not only a price effect, but also an exchange rate effect. Although in the factor market there is a constant change in rents relative to wages, there is a reduction in the production of labor-intensive goods to be exported, worsening the balance of trade. ${ }^{8}$ This result violates the SST, since it would be expected that the increase in the export/import price ratio would lead to a decrease in the capital/ labor wage ratio, but the latter was constant.

The overall performance of the Brazilian economy, for the first simulation, shows improvements in absorption, imports, private consumption, household income, composite supply and in household welfare for both agricultural and nonagricultural sectors. Such results are expected as long as the imported goods are not ideal substitutes for the goods produced domestically.

In the second simulation, with $\sigma_{Q}>1$, there is no violation of the SST. In addition to the expected depreciation in the exchange rate when the import price decreases (the price of similar domestic good decreases), there is also an expected

8 In equation (4), section 3, the value of $\Phi$ represents a deficit in the balance of trade, reducing the gap between capital rent and wage. 
decrease in the production of a similar domestic good and an increase in exports. As long as the export good is labor intensive, it should be expected that the wage would increase more relative to the price of capital, what is exactly shown in table 2. There are improvements in absorption, GDP, private consumption, volume of trade, indirect taxes, household income, composite commodity supply, and welfare.

Table 2 - CGE Model Simulation Results for Scenario 2 (\% changes from base values)

\begin{tabular}{lcc}
\hline \multicolumn{1}{c}{ Variable } & Simulation I (a) & Simulation 2 (b) \\
\hline Absorption & 2.2 & 2.3 \\
GDP & 0.13 & 0.19 \\
Private Consumption & 3.4 & 3.6 \\
Agricultural Exports & -0.9 & 5.3 \\
Nonagricultural Exports & -0.7 & 4.4 \\
Agricultural Imports & 24.8 & 28.9 \\
Nonagricultural Imports & 24.1 & 29.8 \\
Net Indirect Taxes & 0.87 & 1.28 \\
Exchange Rate & -1.8 & 5.6 \\
Rural Households Income & 2.35 & 2.35 \\
Urban Households Income & 2.32 & 2.37 \\
Composite Agric. Commodity Supply & 2.81 & 3.08 \\
Composite Nonagric. Commodity Supply & 2.31 & 2.39 \\
Economy Wide Price of Capital & 2.25 & 2.21 \\
Economy Wide Price of Labor & 2.25 & 2.22 \\
Economy Wide Price of Land & 2.19 & 2.66 \\
Equivalent Variation for Urban households & 3.4 & 3.6 \\
Equivalent Variation for Rural households & 3.4 & 3.6 \\
Price of Exports (domestic currency) & -1.8 & 5.6 \\
Price of Imports (domestic currency) & -21.5 & -15.5 \\
\hline Source: Elaborated by the author & & \\
\hline
\end{tabular}

Source: Elaborated by the author.

Note: (a) Simulation $1=20 \%$ decrease in world prices of imported goods with $\mathrm{s}_{\mathrm{Q}}=0.8$; (b) Simulation $2=20 \%$ decrease in world prices of imported goods with $\mathrm{s}_{\mathrm{Q}}=1.41$.

\section{Final Considerations}

This study shows some of the possible generalization problems from the traditional neoclassical approach, specifically the SST, using a CGE model. It was showed, through a standard CGE model with different degrees of substitutability between imports and domestic goods that the Stolper-Samuelson Theorem (SST) holds only when imports and domestic goods are highly substitutable, after changes in exogenous prices of imports.

The empirical results obtained confirmed those theoretical predictions found by Thierfelder and Robinson (2002) and Cheng, Sachs and Yang (2002), that the 
sign of the SST result is opposite to what HOS model would predict when imports and domestic goods are imperfect substitutes. The results also showed that although the reduction in the import tariff generated a small increase in real national income, household income went up, emphasizing that inappropriate trade policy adjustment can stand in the way of promoting rapid and equitable growth of the economy.

Although the limitations of this study in terms of the standard CGE model used and the aggregation level of the Brazilian SAM, the results reflect an extension of the Swan-Salter model, based on Thierfelder and Robinson (2002) and Jones (1965), and generally show that changes in relative factor prices depend not only on changes in commodity prices, as in the SST, but also in changes in the balance of trade ${ }^{9}$ and factor endowments, as showed in section 3 and in the previous section with the simulations results. Agricultural and nonagricultural sectors can get gains from distortions removal and smaller international prices of imported goods. As results show, the households' income and welfare can also be improved through less distortion and smaller prices.

A last, but not least important, observation to be made is that this study proposed to verify empirically a specific result from a theoretical model, which stresses the carefulness about the empirical results to the Brazilian trade policies.

\section{References}

ARMINGTON, P. A. A theory of demand for products distinguished by place of production. IMF Staff Papers, v. 16 n. 1, p. 159-178, 1969.

ASANO, S.; FIUZA, E. Estimation of the Brazilian consumer demand system. Rio de Janeiro: Ipea, 2001. (Discussion Paper, n. 793).

BARROS, R. P. et al. Openness and income distribution in Brazil. Proceedings of the Workshop on Trade Liberalization and the Labor Market in Brazil. Brasília, DF: UnB/Ipea, 2000.

BAUTISTA, R. et al. Policy bias and agriculture: partial and general equilibrium measures. Review of Development Economics, v. 5, n. 1 89-104, 2001.

BAUTISTA, R.; THOMAS, M. Income effects of alternative trade policy adjustments on Philippine rural households: a general equilibrium analysis. Washington, D.C.: IFPRI, 1997. (TMD Discussion Paper n. 22).

BITTENCOURT, M. V. L. The impacts of trade liberalization and macroeconomic instability on the Brazilian economy. 2004. 262 f. Ph.D. Dissertation (Agricultural, Economics) - The Ohio State University, Ohio, 2004.

BITTENCOURT, M. V. L; LARSON, D.; KRAYBILL, D. A liberalização comercial e os impactos regionais sobre a pobreza e a distribuição de renda no Brasil. Pesquisa e Planejamento Econômico, v. 38 n. 1, 127-166, 2008.

9 Through $\mathrm{F}$ in equation (b), section 3. 
. Regional short-run effects of trade liberalization in Brazil. Economic Systems Research, v. 22 n. 1, 65-85, 2010.

CAMPOS-FILHO, L. Unilateral liberalization and Mercosul: implications for resource allocation. Unpublished Ph.D. Dissertation, University of London, 1998.

CARNEIRO, F. G.; ARBACHE, J. S. The impacts of trade on the Brazilian labor market: a CGE model approach. Export-Led Research Project of the UNDP Office in New York. Preliminary version, 2002.

CARVAlHO, A.; PARENTE, A. Impactos comerciais da ALCA. Rio de Janeiro: Ipea, 1999. (Discussion Paper, n. 635).

CATTANEO, A. Deforestation in the Brazilian Amazon: comparing the impacts of macroeconomic shocks, land tenure, and technological change. Paper presented at the workshop on "Technological Change in Agriculture and Deforestation", Costa Rica, 1999. Resource and Environmental Policy Branch Economic Research Service, USDA, Washington, D.C., 1999.

CATTANEO, A.; HINOJOSA-OJEDA, R.; ROBINSON, S. Costa Rica trade liberalization, fiscal imbalances, and macroeconomic policy: a computable general equilibrium analysis. The North American Journal of Economics and Finance, v. 10, n. 1, p. 39-67, 1999.

CHENG, W.; SACHS, J.; YANG, X. A General equilibrium re-appraisal of the Stolper-Samuelson theorem. Journal of Economics, v. 72, n. 1, p. 1-18, 2002.

CHOU, J.; CHU, Y.; WANG, S. Effects of trade liberalization on Taiwan: a computable general equilibrium analysis. Asian Economic Journal, v. 11, n. 21, p. 169-85, 1997.

DAVIES, R.; RATTSO, S.; TORVIK, R. Short-run consequences of trade liberalization: a computable general equilibrium model of Zimbabwe. Journal of Policy Modeling, v. 20, n. 3, p. 305-333, 1998.

FERREIRA FILHO, J. B.; HORRIDGE, M. Economic integration, poverty and regional inequality in Brazil. In: ANNUAL CONFERENCE ON GLOBAL ECONOMIC ANALYSIS, 7., 2004, Washington, D.C. Proceedings... Washington, D.C: World Bank and Center for Global Trade Analysis, 2004.

. The Doha development agenda and Brazil: distributional impacts. Review of Agricultural Economics, v. 28, n. 3, p. 362-69, 2006.

FLORES, R. G. The gains from Mercosul: a general equilibrium, imperfect competition evaluation. Journal of Policy Modeling, v. 19, n. 1, p. 1-18, 1997.

HADDAD, E. A. Regional inequality and structural changes: Lessons from the Brazilian economy. Aldershot: Ashgate, 1999.

HADDAD, E. A.; AZZONI, C. R. Trade and location: geographical shifts in the Brazilian economic structure. In: GUILHOTO, J. J. M.; HEWINGS, G. J. D. (Ed.). Structure and structural change in the Brazilian economy. Aldershot: Ashgate. 2001.

HADDAD, E. A.; DOMINGUES, E.; PEROBELLI, F. Regional effects of economic integration: the case of Brazil. Journal of Policy Modeling, v. 24, n. 5, 453-482, 2002.

HARRISON, G. et al. Regional, multilateral and unilateral trade policies of Mercosur for growth and poverty reduction in Brazil. In: ENCONTRO NACIONAL DE ECONOMIA, 2002, Nova Friburgo, RJ. Anais... Nova Friburgo, RJ: Anpec, 2002. 
HARRISON, G. et al. Políticas de comércio regionais, multilaterais e unilaterais do Mercosul para o crescimento econômico e a redução da pobreza no Brasil. Pesquisa e Planejamento Econômico, v. 33, n. 1, p. 1-60, 2003.

GOPINATH, M.; ROE, T. Modeling inter-sectoral growth linkages: an application to U.S. agriculture. Agricultural Economics, v. 21, n. 2, p. 131-44, 1999.

HERTEL, T. Applied general equilibrium analysis of agricultural and resource policies. West Lafayette, IN: Purdue University, 1999. (Staff Paper 99-2).

IBGE. Censo agropecuário 1995/1996. Rio de Janeiro: IBGE, 1998.

. Matriz de insumo-produto Brasil 1995. Rio de Janeiro: IBGE, 1997a. . Sistema de contas nacionais Brasil 1990-1995/96. Rio de Janeiro: IBGE, 1997b.

JONES, R. The structure of simple general equilibrium models. Journal of Political Economy, V. 73, n. 6, p. 557-572, 1965.

LEAMER, E. Sources of comparative advantage. Cambridge: The MIT Press, 1984.

LLOYD, P. Generalizing the Stolper-Samuelson theorem: a tale of two matrices. Review of International Economics, v. 8, n. 4, p. 597-613, 2000.

LOFGREN, H.; HARRIS, R.; ROBINSON, S. A standard computable general equilibrium (CGE) model in GAMS. Washington, D.C.: IFPRI, 2001. (TMD Discussion Paper n. 75).

MELO, J.; TARR, D. A general equilibrium analysis of US foreign trade policy. MIT University Press, 1992.

MONTEAGUDO, J.; WATANUKI, M. Evaluating agricultural reform under the FTAA and Mercosur-EU FTA for Latin America A quantitative CGE assessment. In: INTERNATIONAL SEMINAR AGRICULTURAL LIBERALIZATION AND INTEGRATION: WHAT TO EXPECT FROM THE FTAA AND THE WTO? 2002, Washington D.C. Proceedings... Washington D.C.: Inter-American Development Bank, 2002.

RASSEKH, F.; THOMPSON, H. Adjustment in general equilibrium: some industrial evidence. Review of International Economics, v. 5, n. 1, p. 20-31, 1997.

ROBINSON, S.; THIERFELDER, K. A note on taxes, prices, wages, and welfare in general equilibrium models. Washington, D.C.: IFPRI, 1999. (TMD Discussion Paper 39).

THIERFELDER, K.; ROBINSON, S. Trade and tradability: exports, imports and factor markets in the Swan-Salter model. Washington, D.C.: IFPRI, 2002. (TMD Discussion Paper n. 93).

THOMPSON, H. Income redistribution due to international trade and capital in simulated trade models. International Economic Journal, v. 4, n. 2, p. 21-34, 2002.

TOURINHO, O.; KUME, H.; PEDROSO, A. C. Elasticidades de Armington para o Brasil: 19862001. Rio de Janeiro: Ipea, 2002. (Discussion Paper, n. 901). 


\section{APPENDIX A - Adapted model (LOFGREN; HARRIS; ROBINSON, 2001)}

\section{Sets}

$\begin{array}{ll}a \in A & \text { activities } \\ c \in C & \text { commodities } \\ c \in C E(\subset C) & \text { exported commodities } \\ c \in C M(\subset C) & \text { imported commodities } \\ c \in C X(\subset C) & \text { domestic production } \\ f \in F & \text { factors of production }\end{array}$

\section{Parameters}

\begin{tabular}{|c|c|}
\hline$\alpha_{a}^{a}$ & $\begin{array}{l}\text { efficiency parameter in the CES activity } \\
\text { function }\end{array}$ \\
\hline$\alpha_{a}^{\text {va }}$ & $\begin{array}{l}\text { efficiency parameter in the CES value } \\
\text { added function }\end{array}$ \\
\hline$\alpha_{c}{ }^{a c}$ & $\begin{array}{l}\text { shift parameter for domestic commodity } \\
\text { aggregation function }\end{array}$ \\
\hline$\delta_{a}{ }^{a}$ & CES activity function share parameter \\
\hline$\delta_{\mathrm{fa}} \mathrm{va}$ & $\begin{array}{l}\text { CES value added function share parameter } \\
\text { for factor } \mathrm{f} \text { in activity a }\end{array}$ \\
\hline$\theta_{\mathrm{ac},}$ & yield of output c per unit of activity a \\
\hline$\rho_{\mathrm{a}}{ }^{\mathrm{a}}$ & CES production function exponent \\
\hline$\rho_{\mathrm{a}}^{\mathrm{va}}$ & CES value added function exponent \\
\hline$\rho_{\mathrm{c}}^{\mathrm{ac}}$ & $\begin{array}{l}\text { domestic commodity aggregation function } \\
\text { exponent }\end{array}$ \\
\hline
\end{tabular}

$$
\begin{array}{ll}
i \in I N S & \text { institutions } \\
i \in I N S D(\subset I N S) & \text { domestic institutions } \\
i \in I N S D N G(\subset I N S D) & \text { domestic non- } \\
h \in H(\subset I N S D N G) & \text { government institutions } \\
\text { households }
\end{array}
$$ shif $_{\text {if }}$ share for domestic institution $i$ in the
income from $f$
$\mathrm{ta}_{\mathrm{a}} \quad$ tax rate for activity a
$\mathrm{tf}_{\mathrm{f}} \quad$ direct tax rate for factor $\mathrm{f}$
$\operatorname{trnsfr}_{\mathrm{if},} \quad$ transfer from factor $\mathrm{f}$ to institution $\mathrm{i}$
tva $\mathrm{a}_{\mathrm{a}}$ rate of value added tax for activity a
ica c used as intermediate input per unit of final output in a
inta amount of aggregate intermediate input per activity unit
iva amount of aggregate value added input per activity unit




\section{Variables}

\begin{tabular}{|c|c|c|c|}
\hline$\overline{Q F S}_{f}$ & quantity supplied of factor & $\mathrm{QF}_{\mathrm{fa}}$ & demand for factor f from activity a \\
\hline$\overline{W F D I S T_{f a}}$ & $\begin{array}{l}\text { wage distortion factor for factor } \mathrm{f} \text { in } \\
\text { activity a }\end{array}$ & $\mathrm{QHA}_{\text {ach }}$ & $\begin{array}{l}\text { household home consumption of } \mathrm{c} \\
\text { from activity a by household } h\end{array}$ \\
\hline EXR & foreign exchange rate & QINTA $_{a}$ & aggregate intermediate input \\
\hline $\mathrm{PA}_{\mathrm{a}}$ & price of activity a & $\mathrm{QINT}_{\text {ca }}$ & $\begin{array}{l}\text { output of commodity c as } \\
\text { intermediate input to activity a }\end{array}$ \\
\hline PINTA $_{a}$ & $\begin{array}{l}\text { aggregate intermediate input price for } \\
\text { activity a }\end{array}$ & $\mathrm{QVA}_{\mathrm{a}}$ & aggregate value added \\
\hline $\mathrm{PQ}_{\mathrm{c}}$ & composite commodity price & $\mathrm{QX}_{\mathrm{c}}$ & aggregate domestic output \\
\hline $\mathrm{PX}_{\mathrm{c}}$ & producer price & QXAC $_{\mathrm{ac}}$ & output of commodity $\mathrm{c}$ from activity a \\
\hline $\mathrm{PVA}_{\mathrm{a}}$ & value added price of a & $\mathrm{WF}_{\mathrm{f}}$ & average price of factor $f$ \\
\hline $\mathrm{PXAC}_{\mathrm{ac}}$ & $\begin{array}{l}\text { producer price of commodity c for } \\
\text { activity a }\end{array}$ & $\mathrm{YF}_{\mathrm{f}}$ & income of factor $f$ \\
\hline $\mathrm{QA}_{\mathrm{a}}$ & level of activity a & $\mathrm{YIF}_{\text {if }}$ & $\begin{array}{l}\text { income to domestic institution i from } \\
\text { factor } \mathrm{f}\end{array}$ \\
\hline
\end{tabular}

\section{Equations}

Prices:

(1) $P A_{a}=\sum_{c \in C} \theta_{a c} \cdot \mathrm{PXAC}_{a c}$

(2) PINTA $_{a}=\sum_{c \in C} \mathrm{PQ}_{c} . i c a_{a c}$

(Activity Price)

(Intermediate Input Price)

(3) $P A_{a} \cdot\left(1-t a_{a}\right) \cdot Q A_{a}=P V A_{a} \cdot Q V A_{a}+$ PINTA $_{a} \cdot$ QINTA $_{a}$

(Activity Revenues and Costs)

Production and commodity equations:

(4) $Q A_{a}=\alpha_{a}^{a} \cdot\left(\delta_{a}^{a} \cdot Q V A_{a}^{-\rho_{a}^{a}}+\left(1-\delta_{a}^{a}\right) \cdot Q I N T A_{a}^{-\rho_{a}^{a}}\right)^{\frac{1}{\rho_{a}^{a}}}$

(5) $\frac{Q A_{a}}{Q^{\prime N T A_{a}}}=\left(\frac{P I N T A_{a}}{P V A_{a}} \frac{\delta_{a}^{a}}{1-\delta_{a}^{a}}\right)^{\frac{1}{1+\rho_{a}^{a}}}$

(CES Activity Production Function)

(CES Value added-Intermediate-Input Ratio) 
(6) $Q V A_{a}=i v a_{a} \cdot \mathrm{Q} A_{a}$

(Demand for Value Added)

(7) $Q I N T A_{a}=\operatorname{int} a_{a} \cdot Q A_{a}$

(Demand for Intermediate Input)

(8) $Q V A_{a}=\alpha_{a}^{v a} \cdot\left(\sum_{f \in F} \delta_{f a}^{v a} \cdot Q F_{f a}^{-\rho_{a}^{v a}}\right)^{\frac{1}{\rho a^{v q}}}$

(Value added and Factor Demands)

(9) $W_{f} \cdot \overline{W^{\prime} D D I S T_{f a}}=P V A_{a} \cdot\left(1-t v a_{a}\right) \cdot Q V A_{a} \cdot\left(\sum_{f \in F^{\prime}} \delta_{f a}^{v a} \cdot \mathrm{QF}_{f a}^{-\rho_{a}^{v a}}\right)^{-1} \cdot \delta_{f a}^{v a} \cdot \mathrm{QF}_{f a}^{-v a}-1$

(Factor Demand)

(10) $Q I N T_{c a}=i c a_{c a} \cdot Q I N T A_{a} \quad$ (Intermediate Input Demand)

(11) $Q X A C_{a c}+\sum_{h \in H} Q H A_{a c h}=\theta_{a c} \cdot Q A_{a}$ (Commodity Production and Allocation)

(12) $Q X_{c}=\alpha_{c}^{a c} \cdot\left(\sum_{a \in A} \delta_{a c}^{a c} \cdot \mathrm{QXAC}_{a c}^{-\rho_{c}^{a c}}\right)^{\frac{1}{\rho_{c}^{c c}-1}}$ (Output Aggregation Function)

(13) $\mathrm{PXAC}_{a c}=P X_{c} \cdot Q X_{c} \cdot\left(\sum_{a \in A} \delta_{a c}^{a c} \cdot \mathrm{QXAC}_{a c}^{-\rho_{c}^{a c}}\right)^{-1} \cdot \delta_{a c}^{a c} \cdot \mathrm{QXAC}_{a c}^{-\rho_{c}^{a c}-1}$

(First-order Condition for Output Aggregation Function)

Institutions:

(14) $\mathrm{YF}_{i f}=\sum_{a \in A} W F_{f} \cdot \overline{W F D I S T}_{f a} \cdot Q F_{f a}$

(15) $\mathrm{YIF}_{\text {if }}=\operatorname{shif}_{\text {if }} \cdot\left\lfloor\left(1-t f_{f}\right) \cdot \mathrm{YF}_{f}-t r n s f r_{\text {rowf }} \cdot E X R\right\rfloor$ (Institutional Factor Incomes)

System constraints:

$$
\text { (16) } \overline{Q F S}_{f}=\sum_{a \in A} Q F_{f a}
$$

(Factor Market Equilibrium) 
APPENDIX B - Brazilian Social Accounting Matrix (SAM) (CATTANEO, 1999), 1995-96 Aggregated version (1995 billion R\$)

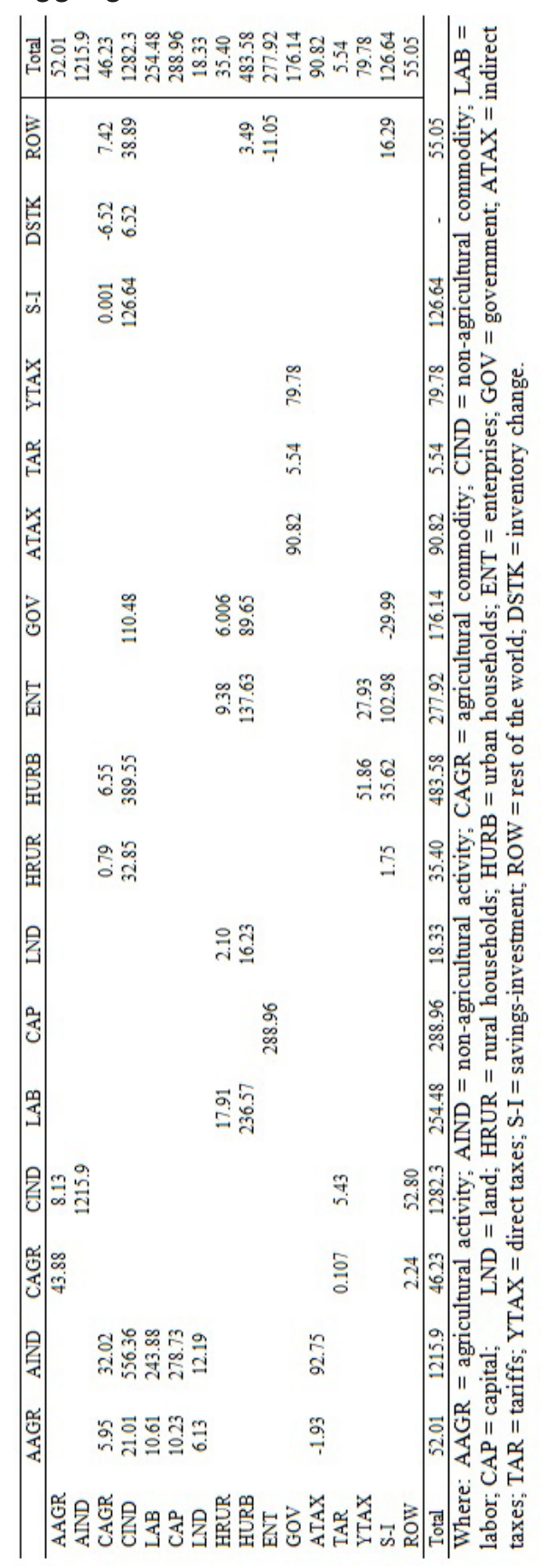

Recebido em: 10/08/2011. Aceito em: 31/03/2013 